\title{
The phytobenthos of the Hornsund fiord, SW Spitsbergen
}

\author{
IRENEUSZ FLORCZYK AND ADAM LATAłA
}

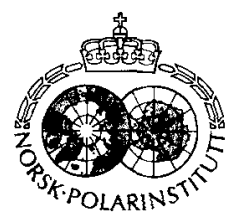

\begin{abstract}
Florczyk, I. \& Latała, A. 1989: The phytobenthos of the Hornsund fiord, SW Spitsbergen. Polar Research 7, 29-41.

The species composition and biomass of material collected in the summers 1981 and 1983 from 69 stations in the Hornsund fiord were analysed. 48 macroalgal taxa were found: 13 green algae, 18 brown algae and 17 red algae. 19 of these taxa were not reported from the nearby Isfjorden.

The overall biomass for the littoral zone varied from 0 to $216 \mathrm{gm}^{-2}$ formalin d.w., although in $\frac{1}{3}$ of samples the biomass was between 20 and $80 \mathrm{gm}^{-2}$. The dominant species were Fucus distichus, Acrosiphonia duriuscula and Pilayella littoralis.

Using cluster analysis, an attempt was made to delimit regions with a characteristic species composition. The results obtained, however, do not permit this in the littoral zone of the Hornsund fiord.
\end{abstract}

Ireneusz Florczyk and Adam Latata, Institute of Oceanography, Gdańsk University, ul. Czotgistów 46, 81378 Gdynia, Poland; June 1988 (revised February 1989).

For some time, Polish scientists have been conducting research in the Hornsund region of Spitsbergen. So far, a preliminary survey of selected animal components of the Hornsund biocoenosis has been carried out (Stempniewicz \& Węslawski 1989; Szaniawska \& Wolowicz 1986; Węsławski 1984). Very few data on the marine algae are available - only a few papers from the second half of the 19th century (Agardh 1862, 1868; Kjellman $1875,1877,1883$ ), and some more recent information on the ecology of the Spitsbergen algae (Svendsen 1959; Latała \& Florczyk 1986).

Geomorphologically, Hornsund is a fiord with a weak threshold lying outside the actual mouth. The coastlines are indented and vary in a mosaiclike fashion over a short distance.

Arctic waters have a relatively low salinity of c. 32-33\%o (Coachman \& Aagaard 1974). That of the Hornsund waters varies in summer from 29 to $34 \%$, the most frequent value being c. $32 \%$ (Swerpel 1983; Urbański et al. 1980). The water temperature at this time fluctuates between 0 and $4^{\circ} \mathrm{C}$ (Swerpel 1983), though greater amplitudes are recorded in inshore waters. Tides in the Hornsund fiord have a range of about $1 \mathrm{~m}$ (Siwecki \& Swerpel 1979), short crested waves may reach heights of $1 \mathrm{~m}$, but swells entering the fiord from the open sea may be 5-6 $\mathrm{m}$ high on the shores (Węsławski 1984).

Illumination is poor owing to the polar night (from mid-November to mid-February) and the low solar elevation during the day. The winter ice cover (November-May) and the ice crust (persisting up until July) which forms in the breaker and tidal zones (Węsławski 1984) further restrict the access of light, and modify phytobenthos growth.

The aim of this paper is to determine the qualitative composition of the phytobenthos and preliminary determination of the part played by the various taxa of the littoral zone in the biomass.

\section{Material and methods}

Material for quantitative analysis was collected in August 1981 from 66 stations located in the littoral zone of the Hornsund fiord at depths down to $1 \mathrm{~m}$ (Fig. 1.). The zero level was set at the upper range boundary of the genus Fucus (Svendsen 1959; Jorde \& Klavestad 1963). Samples were taken from an area of $0.25 \mathrm{~m}^{2}$. The stations were situated on the skerry coasts, and covered only the regions where phytobenthos communities flourished. The material was collected by hand while the tide was out, and was immediately conserved in $4 \%$ formalin.

The qualitative analysis additionally included thalli from three further stations (Nos. 67, 68 and 69 -summer 1983) at which material was collected from depths down to $1 \mathrm{~m}$ by hand and from deeper waters by means of a drag net. Algae thrown up 


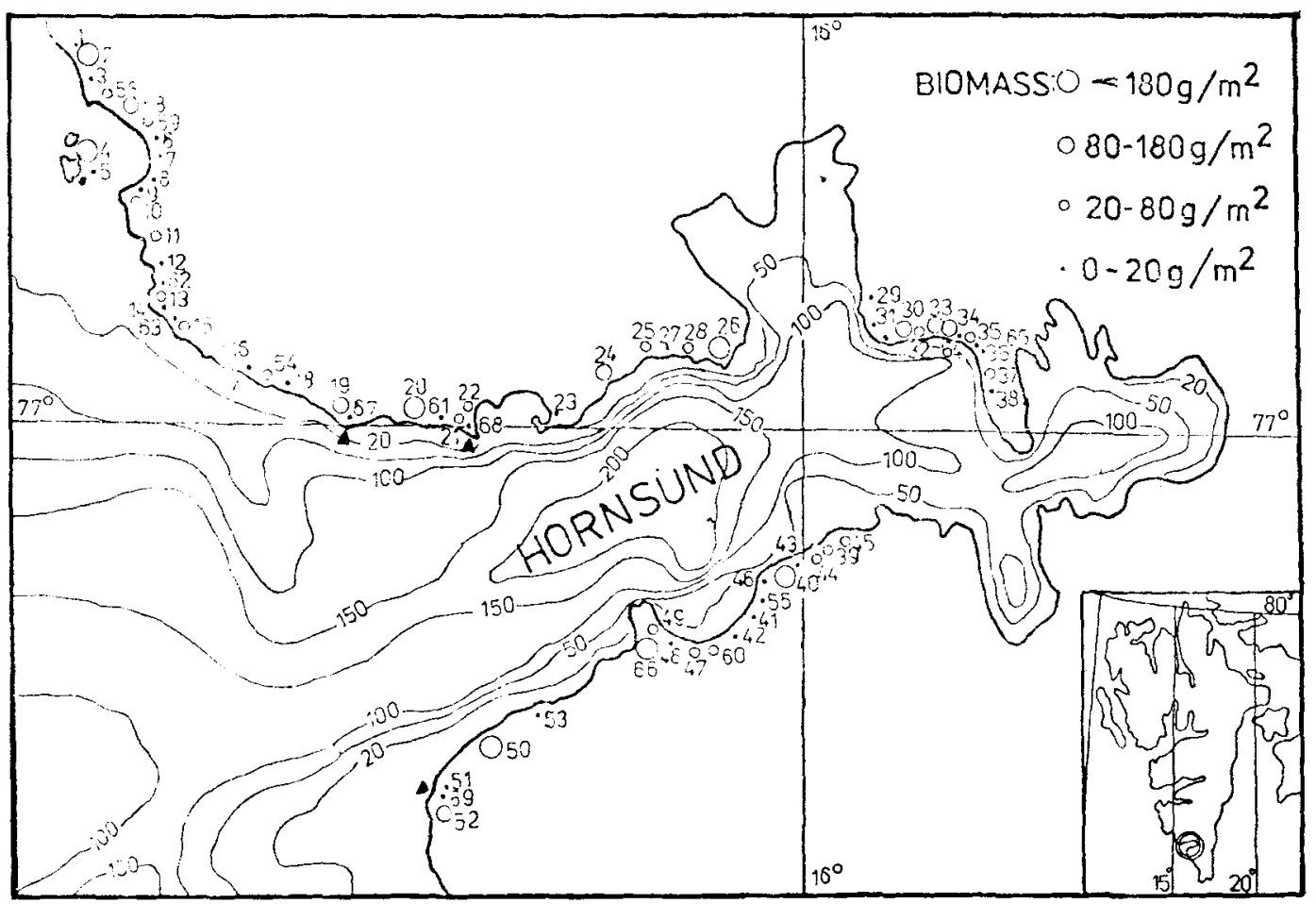

Fig. 1. Distribution of the sampling stations (values of the biomass are marked)

A-stations only for qualitative analysis.

onto the shore during storms were also collected (Fig. 1).

In the laboratory the samples were segregated into taxa, the following keys being used in their identification: H. Kylin $(1944,1947,1949)$, W. R. Taylor (1957), K. L. Vinogradova (1979) and A. D. Zinova $(1953,1955)$. The material intended for quantitative analysis was dried to constant mass at $60^{\circ} \mathrm{C}$.

Cluster analysis was applied in order to ascertain whether there might be any similarities in the species content between individual stations or links between species. Two kinds of clustering were used: 1) the objects were taxa, the factors describing them being the stations at which the taxa occurred; 2) the objects were stations, the factors describing them being the set of taxa identified in all samples.

The cluster analysis was carried out only on the basis of data from stations located in the littoral ( 66 stations, August 1981), with the exception of those at which there was no phytobenthos. Data from 52 stations were thus analysed. The number of taxa was also restricted to those species definitely known to occur in the littoral.

The data were encoded in a zero-one system. The Squared Euclidean Distance (Abbott et al. 1985) and the following clustering methods UPGMA, WPGMA, Flexible Sorting, Centroid Sorting, Ward Method, Single Link, Complete Link (Abbott et al. 1985) - were applied. Dendrograms representing the system of clusters obtained in the greatest number of groupings were chosen to interpret. Calculations were carried out on an Amstrad PC 1512 computer with the aid of the Cluster Programme (Florczyk 1989).

\section{Results}

\section{Qualitative analysis}

This revealed the presence of 48 macroalgal taxa13 green algae, 18 brown algae and 17 red algae. Species also recorded by Svendsen (1959) in Isfjorden are marked with an asterisk * 


\section{Chlorophyta}

Acrosiphonia arcta (Dillwyn) J. Agardh (Fig. $5 \mathrm{a}, \mathrm{b})$. - This species rarely occurred in the littoral. Svendsen (1959) found it in Isfjorden as Spongomorpha arcta which, according to Vinogradova (1979), is a synonym of $A$. arcta.

Acrosiphonia duriuscula (Ruprecht) Yendo*. Thalli were abundant, mostly in the lower littoral. The cells in the central part of the thallus were distinctly wider than in the previous species, ranging from 90 to $150 \mu \mathrm{m}$. The length:width ratio diminished towards the end of the filament.

Blidingia minima (Nag. ex Kutz.) Kylin*. - Found in one sample.

Chaetomorpha melagonium (Weber et Mohr) Kutzing. - Occurred rarely as filaments a few $\mathrm{cm}$ long.

Enteromorpha prolifer (O. F. Muller) J. Agardh*. - Sporadic littoral species.

Pringsheimiella scutata (Reinke) Marchewianka* (Plate 1a). - Epiphyte, especially on Rhodomela subfusca and Ptilota plumosa. Rare sublittoral species.

Ulothrix flacca (Dillwyn) Thuret* (Plate 1b). Filaments c. $30 \mu \mathrm{m}$ wide, cells thick-walled. Length: width ratio of cells $0.3-1: 1$. No squat cells observed.

Ulothrix implexa Kutzing*. - Filaments 8-12.5 (14) $\mu \mathrm{m}$ wide seen. Length:width ratio of cells 10.5-1:1. Cell wall $3 \mu \mathrm{m}$ thick. Abundant littoral species.

Ulothrix pseudoflacca Wille. - Thalli have the structure typical of this species. Frequent.

Ulvaria obscura (Kutzing) Gayral* (Plate 1c,d). A rare species. The thickness of thallus patches at the top, and in the centre ranged from 35 to $41 \mu \mathrm{m}$. In cross-section the cells were about twice as high as they were wide.

Urospora elongata (Rosenvinge) Hagem*. - Rare littoral species. Filament width at the base of filament $19 \mu \mathrm{m}$. The cell length in this part of the thallus was 2 or even 4 times its width. The cells at the top of the thallus were only slightly swollen.
Urospora penicilliformis (Roth) Areschoug. Abundant in the Hornsund fiord.

Urospora wormskioldii (Martens in Hornem)

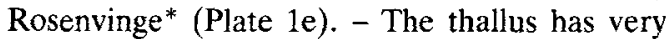
large cells, up to $1 \mathrm{~mm}$ wide in the upper part. Filaments from the cells of which zoospores were released were observed. A frequent species in the littoral.

\section{Phaeophyta}

Alaria grandifolia J. Agardh. - Occurs in the sublittoral.

Alaria membranacea J. Agardh. - Thalli of this species occurred in the sublittoral. The foliose part was wide and without transverse indentation. The sporophiles were similar in shape to those of A. esculenta.

Chorda tomentosa Lyngbye. - Rare littoral species.

Chordaria flagelliformis (O. F. Muller) C. Agardh* (Fig. 5d). - Abundant in a variety of morphological forms. Thalli differed in their branching or number of branch orders. The crosssection of all forms displayed the typical $C h$. flagelliformis structure (Zinova 1953; Taylor 1957).

Desmarestia aculeata (L.) Lamouroux. - Two forms were found: typica Sin. and viridescens A. Zinova, both in the sublittoral.

Dictyosiphon foeniculaceus (Hudson) Greville (Fig. 5c, Plate 2a).--Present both in the littoral and the sublittoral. The thalli exhibited morphological differences in branching, the number of branching orders and colour.

Ectocarpus siliculosus (Dillwyn) Lyngbye* (Plate 1f, g). - Morphologically the thalli display great differences, especially as regards plurilocular sporangia. Both alternate and opposite branching were observed. The plurilocular sporangia varied from 56 to $250 \mu \mathrm{m}$ in length and from 21 to $37 \mu \mathrm{m}$ in width, and terminated in a hair, or were hairless. Russell (1966) reports these characters as occurring in different varieties of $E$. siliculosus. No unilocular sporangia were found. Rare littoral species. 
Elachista fucicola (Valley) Areschoug (Plate 2b). - Exclusively epiphytic on other algae (Dumontia incrassata, Halosaccion sp., Fucus vesiculosus). Frequent in the littoral but also found in the sublittoral.

Fucus distichus subsp. evanescens Linneaus emend. Powell*. - Identified from Powell's (1957) description. These algae were abundant both in the littoral and sublittoral. Great differences in thallus size were recorded: from $2 \mathrm{~cm}$ long dwarf specimens in the littoral to large ones $20-30 \mathrm{~cm}$ long in the sublittoral.

Petalonia zosterifolia (Reinke) O. Kuntze*.Rare littoral species. General outline and crosssectional structure typical.

Laminaria cucullata f. typica (Kjellman) A. Zinova*. - Rare sublittoral species. Unlike $L$. digitata, the lamina had less clearly defined foliose patches and short indentations.

Laminaria digitata (Hudson) Lamouroux. Abundant sublittoral species.

Laminaria saccharina (Linnaeus) Lamouroux. Abundant sublittoral species. Also seen: L. zaccharina f. grandis Kjellman.

Laminaria solidungula J. Agardh. - Rare sublittoral species.

Phyllaria lorea (Bory) Kjellman*. - Only young thalli were reported. The general outline and structure of the pedicel in the cross-section corresponded to the description of $P$. lorea given by Zinova (1953). Svendsen (1959) states that according to Rosenvinge, this species is a juvenile form of $P$. dermatodea.

Pilayella littoralis (Linnaeus) Kjellman. - Species abundant in the littoral, also reported from the sublittoral. There were very many unilocular sporangia but few plurilocular sporangia present in the material.

Sphacelaria arctica Harvey*. - This species occurred in the sublittoral, and unilocular sporangia $70 \mu \mathrm{m}$ in diameter were reported, whereas in Isfjorden Svendsen (1959) collected only sterile thalli.

Sphacelaria plumosa Lyngbye. - Epiphyte in the sublittoral.

\section{Rhodophyta}

Dumontia incrassata (O. F. Muller) Lamouroux* . - Thalli comprising slightly branched or unbranched filaments with flattened sections were observed. The filaments were $1-2 \mathrm{~mm}$ wide. The filaments were smooth without prolifications, attached to the substratum by means of basal cell. Some filaments had pointed ends. Frequent in the lower littoral, especially in exposed localities.

Callophylis cristata (C. Ag.) Kützing. - Present in a few samples.

Halosaccion arcticum A. Zinova*. - Unlike Dumontia incrassata, the thalli of this species were more branched, all had pointed ends, and the filaments were tubular without flattened sections. No prolifications in the thalli.

Halosaccion ramentaceum f. robustum Kjellman. - This form was distinguished because of its long prolifications.

Membranoptera alata (Hudson) Stackhouse*. Rare sublittoral species.

Odonthalia dentata (Linnaeus) Lyngbye. - Thalli from a few to $15 \mathrm{~cm}$ long. Present in the sublittoral.

Palmaria palmata (L.) O. Kuntze. - Present in the sublittoral.

Pantoneura baerii (Postals et Ruprecht) Kylin. This species was reported from the sublittoral. The tetrasporangia were situated on broadened ends of branches. Thallus brittle.

Phycodrys rubens (L.) Batters*. - Thalli occurred in the sublittoral in a variety of morphological forms from several to $20 \mathrm{~cm}$ long. The foliose thalli have darker veins.

Polysiphonia arctica J. Agardh. - Rare sublittoral species.

Polysiphonia nigrescens (Huds.) Greville* . -Filaments contained 14-20 siphons. Some thalli with well-developed reproductive organs. A sublittoral species.

Polysiphonia urceolata (Lightfoot) Greville*.Thalli were found in the sublittoral. They con- 
sisted of filaments over $40 \mu \mathrm{m}$ wide at the upper end, and contained 4 siphons.

Ptilota plumosa (Linnaeus) Agardh. - Branched thalli up to $20 \mathrm{~cm}$ in length were present in the sublittoral.

Rhodochorton spetsbergense Kjellman* (Plate $2 c)$. - Rare sublittoral species.

Rhodomela subfusca (Woodward) C. Agardh* (Plate 2d). - Thallus covered with fine, sharplypointed branchlets lighter in colour than the rest of the thallus. The thalli themselves were also branched. Reproductive organs noted.

Rhodomela lycopodioides (Linneaus) J. Agardh. - Rare sublittoral species.

Rhodophyllis dichotoma (Lepeschkin) Gobi. Present in the sublittoral.

Diatoms of Navicula sp. (Plate 1h), which formed jelly-like filaments, were also present in one of the samples from the littoral.

\section{PILAYELLA LITTORALIS}

\section{WIIII OTHERS}

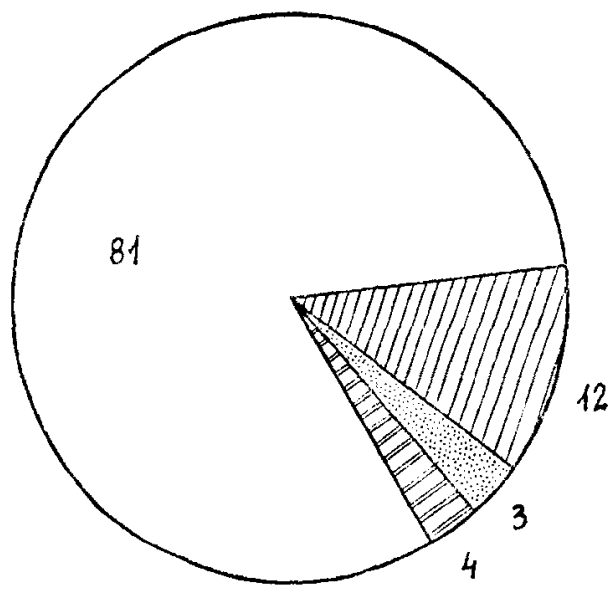

\section{$\square$ fuCUS DISTICHUS}

\section{UIDTACROSIFHONIA DLRIUSCLLA}

Fig. 2. Relationship between the littoral species bjomass. Figures - percentage of total biomass.

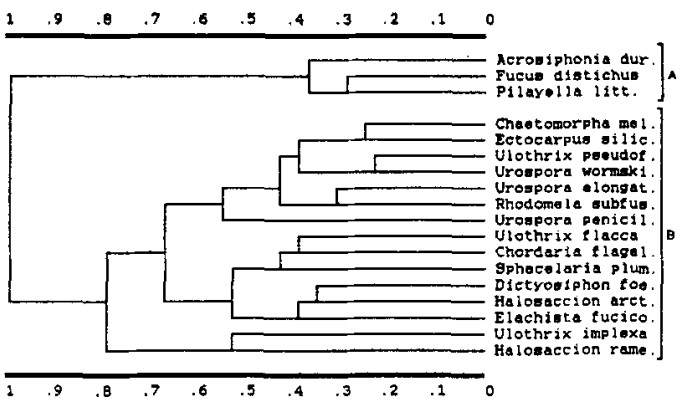

Fig. 3. Clustering 1): Squared Euclidean Distance, Flexible Sorting.

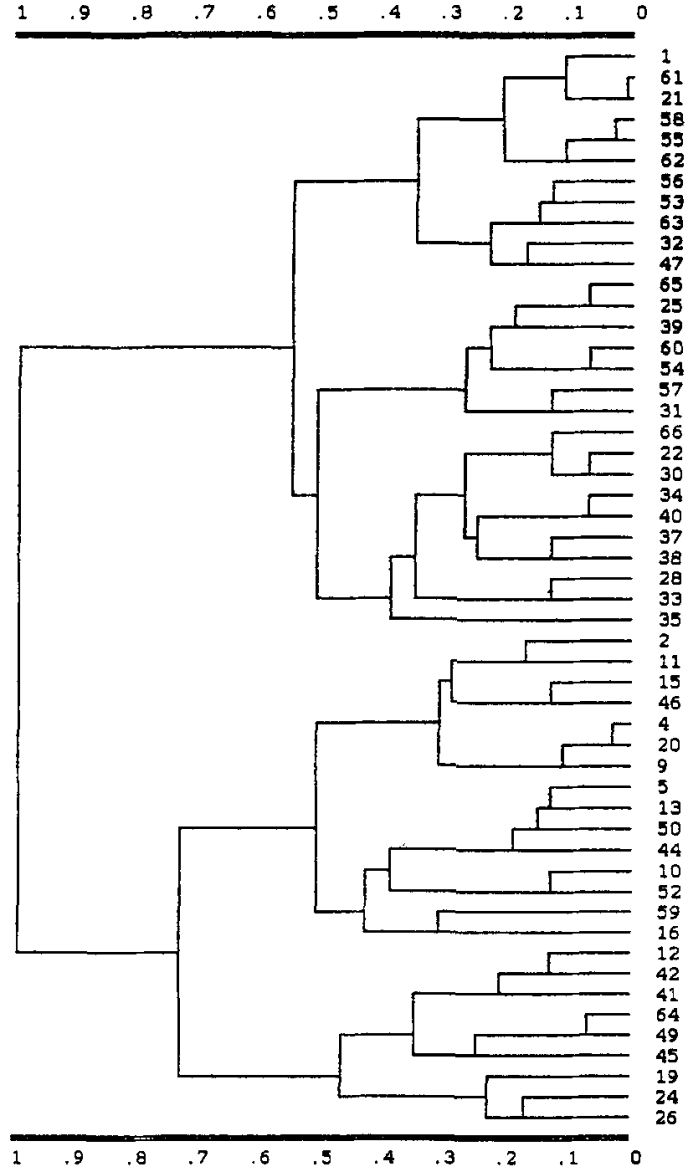

Fig. 4. Clustering 2): Squared Euclidean Distance, Flexible Sorting. 
Table 1. Occurrence of macroalgae of the littoral zone at the station studied.

+- taxon present

- no algae at station

\begin{tabular}{|c|c|c|c|c|c|c|c|c|c|c|c|c|c|c|c|c|c|c|c|c|}
\hline Taxa & 1 & 2 & * & 4 & 5 & $\begin{array}{ll}* & * \\
6 & 7\end{array}$ & * & & & & $13 \stackrel{*}{14}$ & & $\begin{array}{rrr} & * & * \\
16 & 17 & 18\end{array}$ & & & $22 \quad \begin{array}{c}* \\
23\end{array}$ & & & $\stackrel{*}{*}$ & \\
\hline Acrosiphonia duriuscula & & + & & + & + & & & & & + & + & & + & ++ & + & + & & ++ & & + \\
\hline Chaetomorpha melagonium & + & + & & & + & & & & + & & + & + & + & + & & + & & & & \\
\hline Chordaria flagelliformis & & + & & + & + & & & + & + & & & + & & & + & & $+t$ & + & & + \\
\hline Dictyosiphon foeniculaceus & & + & & & + & & & + & + & & + & + & + & + & & + & $+t$ & + & & \\
\hline Ectocarpus siliculosus & & & & + & + & & & & & & + & & & & & & & & & \\
\hline Elachista fucicola & & + & & & + & & & & & & + & + & + & & & + & + & + & & + \\
\hline Fucus distichus & + & + & & + & + & & & + & & & & + & + & + & & + & & ++ & & + \\
\hline Halosaccion arcticum & & + & & & + & & & + & & & + & + & + & + & & & + & & & + \\
\hline Halosaccion ramentaceum & + & + & & + & & & & & + & & & & + & & & & + & + & & \\
\hline Pilayella littoralis & + & + & & + & + & & & ++ & + & & + & + & + & ++ & + & + & & ++ & & + \\
\hline Rhodomela subfusca & & & & & + & & & + & & & & + & & + & & & & & & \\
\hline Sphacellaria plumosa & & + & & & + & & & ++ & ++ & & + & & + & ++ & + & & & + & & + \\
\hline Ulothrix flacca & & & & + & & & & & & & & & + & + & & & + & + & & + \\
\hline Ulothrix implexa & + & + & & + & & & & & & & & + & & & + & & & + & & + \\
\hline Ulothrix pseudoflacca & & & & & & & & & & & & & & & & & + & & & + \\
\hline Urospora elongata & & & & & & & & & & & & & & & & & & & & + \\
\hline Unospora penicilliformis & & + & & & & & & & & & & & & + & & & + & + & & \\
\hline
\end{tabular}

\section{Quantitative analysis}

The overall biomass of the phytobenthos in the littoral zone of the Hornsund fiord ranged from 0 to $216 \mathrm{gm}^{-2}$ formalin d.w. Biomasses exceeding $160 \mathrm{gm}^{-2}$ were only rarely recorded. Most commonly ( 28 stations), the biomass was between 0 and $20 \mathrm{gm}^{-2}$ (Fig. 1).

Fucus distichus, Acrosiphonia duriuscula and Pilayella littoralis had the highest percentages in the total biomass (Fig. 2).

\section{Distribution of macroalgae}

The macroalgae were present at 52 stations in the littoral zone. Their distribution is shown in Table 1.

The following features occur regularly in type 1) clusters (Fig. 3):

- Acrosiphonia duriuscula, Pilayella littoralis and Fucus distichus were always present in a single, clearly defined cluster at the $60 \%$ similarity level. This was cluster A.

- the other taxa were clearly separated into cluster B.

These results were present in most of the dendrograms.
In type 2) clusters (Fig. 4) the objects were linked together in various ways (depending on the clustering method). Each dendrogram presented a different system of clusters; there were no similar results.

\section{Discussion}

According to Svendsen (1959), some littoral species recorded previously in this region have increased their biomass and frequency of occurrence, and the number of littoral species has risen. He reported 8 chlorophytes, 13 phaeophytes and 4 rhodophytes from Isfjorden. Our data (the number of littoral taxa, biomass and frequencies of occurrence of algae) from the Hornsund fiord are difficult to compare with Svendsen's figures. He separated the littoral species from the sublittoral ones very carefully, but as he emphasizes, this is very difficult, and should be considered with criticism. The technique of collecting material for the present analysis precluded such a separation. Moreover, many of the genera cited in the two papers are represented by different species, the systematic position of which is still often unclear.

Three species, Fucus distichus, Pilayella lit- 
$2930313233 \quad 3435363738394041424344 \quad 4546474849505152535455565758596061 \quad 6263 \quad 64 \quad 65 \quad 66$

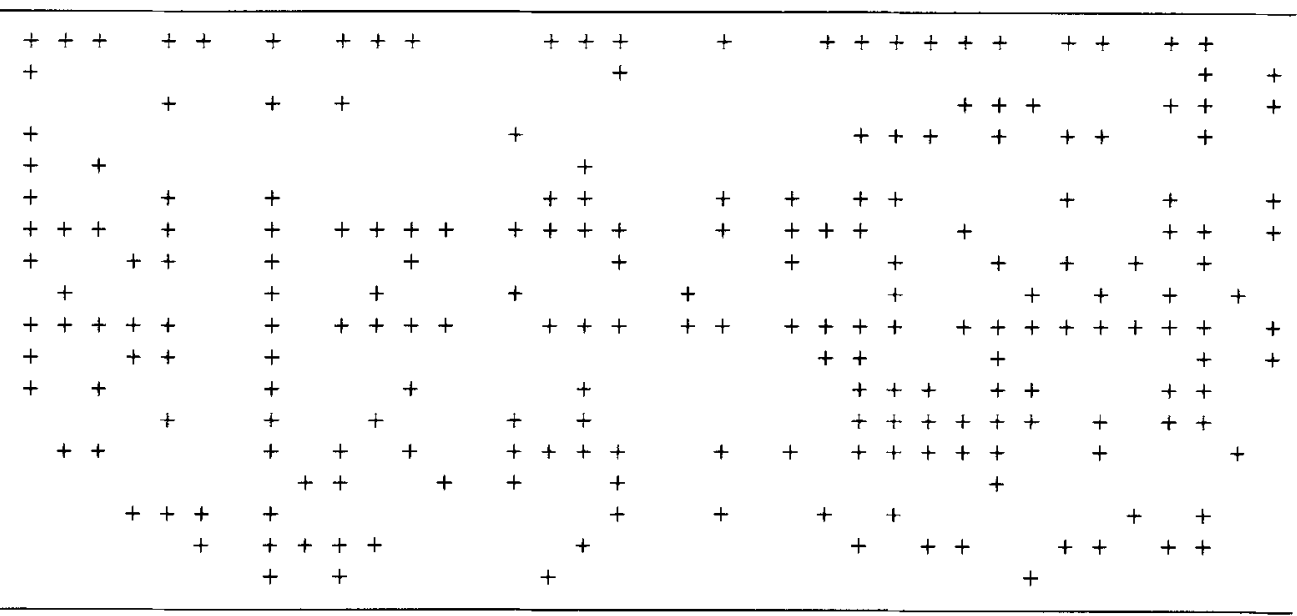

toralis and Acrosiphonia duriuscula, occurred together in the majority of the samples (Table 1), and made up a community typical of the Hornsund fiord. The type 1) clusters demonstrate this. On the dendrogram (Fig. 3) they appear as cluster A. Cluster B comprises species frequently recorded in the samples, but less commonly than the cluster A species. $P$. littoralis was almost always found growing epiphytically on $F$. distichus, but many thalli of the former species were noted as separate entities or in combination with other algae (from cluster B). Likewise, $A$. duriuscula did not always occur together with $F$. distichus and $P$. littoralis, and in 17 samples it was found with some cluster B species.

Stations 50, 4 and 26 were very characteristic. The highest number of taxa recorded were: 17 at station 50, 18 at station 26 and 20 at station 4 ; no more than 13 taxa were recorded from any of the other stations. These were also the stations where the rarest taxa, Odonthalia dentata, Membranoptera alata and Pantoneura baeri, were collected.

The highest biomass was recorded at station 50 $\left(216 \mathrm{gm}^{-2}\right)$. The biomass of the various taxa was slightly lower, but was nevertheless comparable with other figures from Arctic seas (Lomniewski et al. 1979). As in Isfjorden (Svendsen 1959),

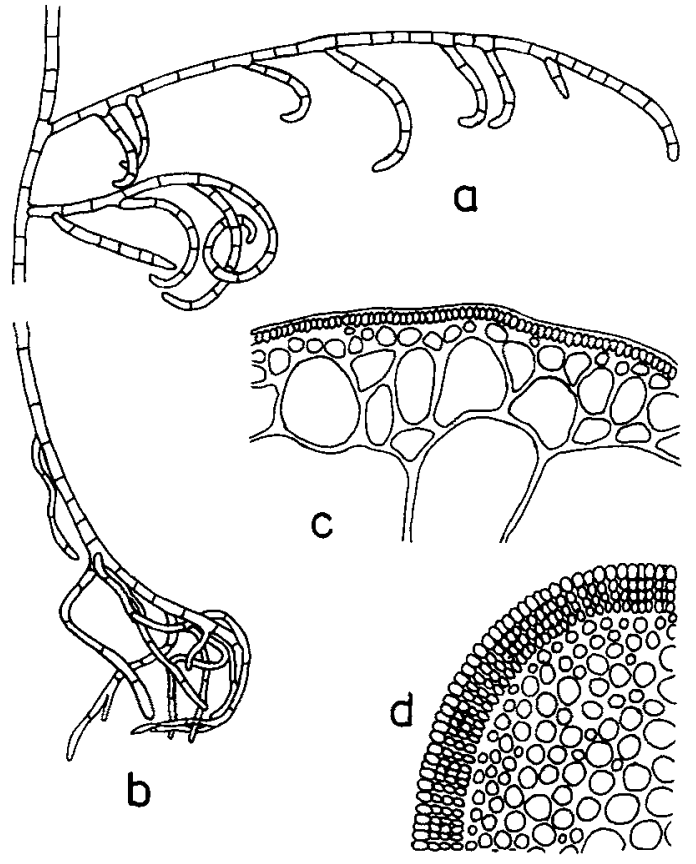

Fig. 5. a), b) Acrosiphonia arcta: a - lateral ramification in the middle part of the plant. Mag. $75 \times . \mathrm{b}$ - the lower part with rhizoids. Mag. 40x.

c) Dictyosiphon foeniculaceus, cross-section. Mag. $300 \times$.

d) Chordaria flagelliformis, cross-section. Mag. 375x. 
Fucus distichus and Pilayella littoralis constituted the greatest proportion of the biomass (Fig. 2). The third largest component of the biomass and most frequently occurring alga in the Hornsund fiord, Acrosiphonia duriuscula, did not occur at all in Isfjorden; there it was replaced by Chordaria flagelliformis and Ralfsia sp. It is hard to say whether this was due to changes in the species composition and biomass of the phytobenthos in the South Spitsbergen region which could have taken place since Svendsen's research, or to the difference between the environments of the two fiords.

The quantity of the biomass at particular stations did not depend on the area of the fiord. Quite near the station with the highest biomass were stations where biomasses were low or mediocre.

The same trends in the Hornsund fiord phytocoenosis are clearly shown by analysing the clusters, especially those obtained by type 2 ) clustering, in which the clusters from stations in any one area are indistinguishable (Fig. 4). These results suggest that there is not really any such definite regionalisation in the littoral zone of the fiord. Those differences in species content and biomass which can be detected between stations result chiefly from the type of substratum and exposure of the localities, e.g. wave motion and ice scouring, which frequently change along short sections of the coast.

\section{References}

Abbott, L. A., Bisby, F. A. \& Rogers, D. J. 1985: Taxonomic analysis in biology. Computers, models and databases. Columbia Univ. Press. New York. 332 pp.

Agardh, J. G. 1862: Om Spetsbergens alger. Akademisk program, Lund.

Agardh. J. G. 1868: Bildrag till kännedomen af Spetsbergens alger. K. Suenska Vetensk. Akad. Handl. 7 (8).

Coachman, L. K. \& Aagaard, K. 1974: Physical oceanography of Arctic and subarctic seas. Pp. 1-72 in Marine Geology and Oceanography of the Arctic Seas. Springer Verlag, Berlin, Heidelberg, N.Y.

Florczyk, I. 1989: The cluster analysis package CLUSTER. Software for IBM PC/XT/AT distributed by PHU 'EDEX' Gdańsk.

Jorde, J. \& Klavestad, N. 1963: The natural history of the Hardangerfjord, 4. The benthonic algal vegetation. Sarsia 9. $99 \mathrm{pp}$.
Kjellman, F. R. 1875: Om Spetsbergens marina, klorofyllforande thallophyter. I. Bilhang till $\mathrm{K}$. Suenska Vetensk. Akad. Handl. 3 (7).

Kjellman, F. R. 1877: Om Spetsbergens marina, klorofyllforande thallophyter. II. Bihang till $K$. Suenska Vetensk. Akad. Handl. 4 (6).

Kjellman, F. R. 1883: The algae of the Arctic Sea. Stockholm. Kylin, H. 1944: Die Rhodophyceen der Schwedischen Westkuste. Lunds Univ. Arsskrift N.F. Avd. 2, 40 (2).

Kylin, H. 1947: Die Phaeophyceen der Schwedischen Westkuste. Lunds Univ. Ärsskrift N.F. Avd. 2, 43 (4).

Kylin, H. 1949: Die Chlorophyceen der Schwedischen Westkuste. Lunds Univ. Årsskrift N.F. Avd. 2, 45 (4).

Latala, A. \& Florczyk, I. 1986: The phytobenthos species composition in the littoral zone of the Hornsund fiord, (SW) Spitsbergen. Zesz. Nauk. Wydz. Biologii, Geografii $i$ Oceanologii Uniwersytetu Gdańskiego. ser. Oceanografia 11, 37-50 (in Polish with English summary).

Lomniewski, K., Zaleski, J. \& Zmudziński, L. 1979: The Arctic Sea. PWN Warszawa (in Polish).

Powell, H. T. 1957: Studies in the genus Fucus L. I. Fucus distichus L. emend Powell. J. mar. biol. Ass. U.K. 36, $407-$ 432.

Russell. G. 1966: The genus Ectocarpus in Britain 1. The attached forms. J. mar. biol. Ass. U.K. 46, 267-294.

Siwecki, R. \& Swerpel, S. 1979: Oceanographical studies in the Hornsund fiord in 1974-1975. Zesz. Nauk. Wydz. BiNoZ U.G. Oceanografia 6, 45-58.

Stempniewicz, L. \& Węslawski, J. M. 1989: Outline of trophic relations in Hornsund-SW Spitsbergen (with special reference to the sea birds). Polish Polar Res. (in press).

Svendsen, P. 1959: The algal vegetation of Spitsbergen. Norsk Polarinstitut Skrifter 116. 49 pp.

Swerpel, S. 1983: Hydrological investigations of the coastal waters in the Hornsund fiord in the summer of 1975. Acta Univ. Wratislaviensis 525, 235-246.

Szaniawska, A. \& Wolowicz, M. 1986: Changes in the energy content of common species from Hornsund, southwest Spitsbergen. Polar Res. 4 n.s., 85-90.

Taylor, W. R. 1957: Marine algae of the northeastern coast of North America. Univ, of Michigan Press, Ann Arbor.

Urbański, J., Neugebauer, E., Spacjer, R. \& Falkowska, L. 1980: Physico-chemical characteristics of the waters of Hornsund fjord on south-west Spitsbergen (Svalbard Archipelago) in summer season 1979. Polish Polar Res. 1(4), 4352.

Vinogradova, K. L. 1979: Key for identification of algae from far-eastern seas of the USSR. Green algae. Nauka, Leningrad (in Russian).

Węsławski, J. M. 1984: Amphipoda (Crustacea) from coastal waters of SW Spitsbergen. Ph.D. thesis, Institute of Oceanography, Gdańsk University, Gdynia.

Zinova, A. D. 1953: Key for identification of brown algae from northern seas of the USSR. Izdatielstvo Akademij Nauk SSSR. Moskva, Leningrad (in Russian).

Zinova, A. D. 1955: Key for identification of red algae from northern seas of the USSR. Izdatielstvo Akademij Nauk SSSR. Moskva, Leningrad (in Russian). 
Plates 
38 I. Florczyk \& A. Latata

\title{
Plate 1
}

\author{
a - Pringsheimiella scutata \\ $\mathrm{b}$ - Ulothrix flacca \\ c - Ulvaria obscura, cross-section \\ d - Ulvaria obscura, surface of thallus \\ e - Urospora wormskioldii, releasing zoospores \\ f, $g-$ Ectocarpus siliculosus, plurilocular sporangia \\ $\mathrm{h}-$ Navicula $\mathrm{sp}$.
}




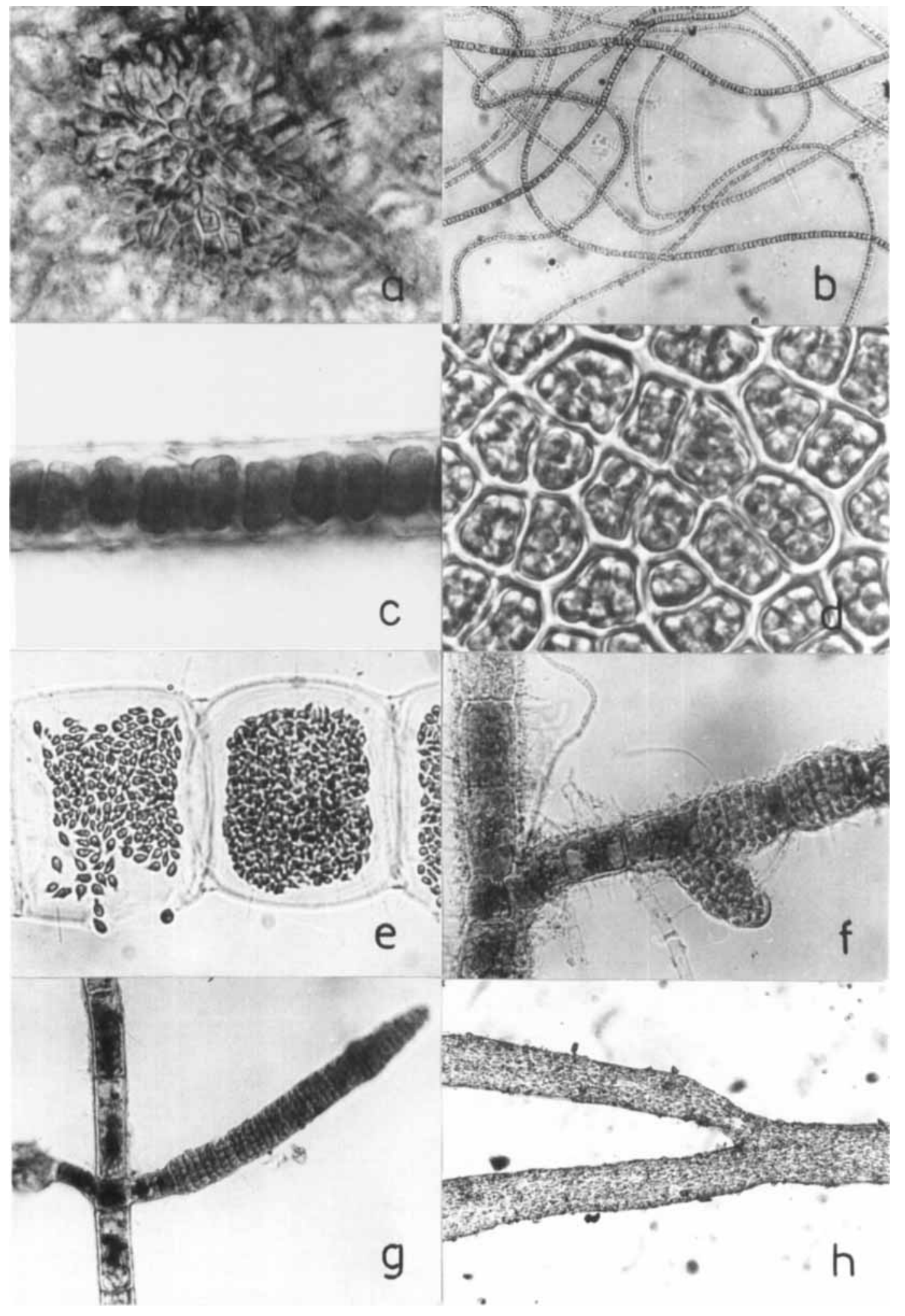


40 I. Florczyk \& A. Latala

Plate 2

a - Dictyosiphon foeniculaceus

b - Elachista fucicola, unilocular sporangia

$c$ - Rhodochorton spetsbergense

$\mathrm{d}$ - Rhodomela subfusca 
The phytobenthos of the Hornsund fiord, SW Spitsbergen 41

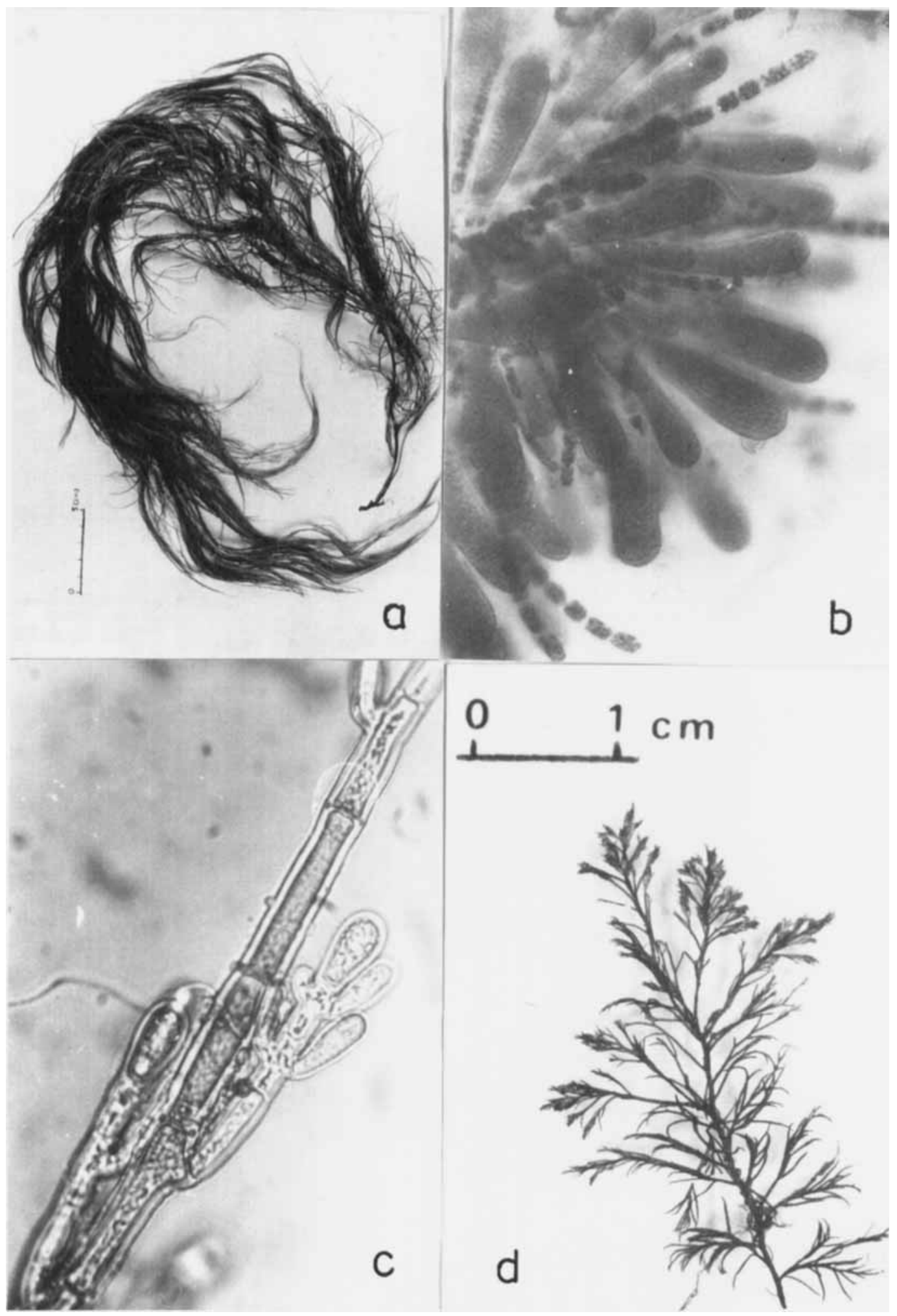


